\title{
Studies with Sanguinarine Like Alkaloids as Feed Additive in Broiler Diets ${ }^{1}$
}

- Author(s)
Vieira SL
Berres J
Reis RN
Oyarzabal OA
Coneglian JLB
Freitas DM
Peña JEM
Torres CA
Presented at Conferência APINCO de
Ciência e Tecnologia Avícolas, Santos - SP,
p.48-49, 2006.

Mail Address

Departamento de Zootecnia

Universidade Federal do Rio Grande do Sul

Av. Bento Gonçalves, 7712

91.540-000. Porto Alegre, RS, Brazil.

Phone/FAX: 555133086048

E-mail: slvieira@ufrgs.br

\section{Keywords}

Broilers, feed additive, Sangrovit ${ }^{\circledR}$, sanguinarine.

\section{ABSTRACT}

This research included two studies evaluating the live performance of broilers fed Sangrovit ${ }^{\circledR}$ (minimum of $1.5 \%$ sanguinarine, a quaternary benzo[c]phenanthridine alkaloid extracted from Macleaya cordata). Both studies were conducted using Ross 308 female broiler chicks. Birds were fed corn-soybean meal all-vegetable diets without growth promoters with 5 treatments and 8 replications in each study. In the first study, treatments were composed of a Negative Control without feed additive and four diets with graded increases of Sangrovit of 12.5, 25,37.5, and $50 \mathrm{ppm}$. In the second study, chicks received a similar diet from placement to 21 days of age and subsequently were given feeds with graded reductions in crude protein (CP) as follow: a Negative Control with $19.7 \%$ CP without sanguinarine, and then 19.7, 19.2, 18.8 and $18.3 \%$ CP supplemented with Sangrovit at $20 \mathrm{ppm}$. It was demonstrated that body weight was increased when birds were fed $50 \mathrm{ppm}$ of Sangrovit at $21 \mathrm{~d}$ when compared to the Negative Control. Also comparatively to the Negative Control, cumulative feed conversion was improved for birds fed with Sangrovit at $37.5 \mathrm{ppm}$ as well as feed intake from placement to 7 days at $12.5 \mathrm{ppm}$. No differences were observed in feed intake. Birds supplemented with Sangrovit and $18.8 \%$ CP had similar body weight gain and feed intake as the Negative Control with $19.7 \%$ CP. Mortality in both studies was not correlated with the treatments. Results from both studies indicate benefits of the supplementation of Sangrovit in diets for broilers.

\section{INTRODUCTION}

A great deal of controversy remains on the use of antimicrobials added to broiler feeds. Epidemiological events that result in antimicrobial resistance by bacteria are difficult to study, and several factors, including the overuse or misuse of antimicrobials in human and veterinary medicine, may intensify the severity of the problem (Shea, 2004). Growth promoters have been banned in European countries and voluntarily withdrawn by some producers in order to supply specific market demands. There has been an increase in the research on alternatives to growth promoters, including plant extracts. The use of natural antimicrobials produced from herbs and spices lends itself to more favorable acceptance by the general public as well as by countries that restrict the imports of products derived from animals fed antibiotics (Dickens \& Ingram, 2001). Active compounds obtained from plants have been used for a variety of human needs for centuries; however, many commercially available additives based on natural extracts lack a definite mode of action in animal feeds.

Natural compounds extracted from plants, such as quaternary benzo[c]phenanthridine alkaloids (QBA) sanguinarine and chelerythrine, 
Vieira SL, Berres J, Reis RN, Oyarzabal OA, Coneglian JLB, Freitas DM, Peña JEM, Torres CA
Studies with Sanguinarine Like Alkaloids as Feed Additive in Broiler Diets

\section{Study 1}

Four hundred one-day-old Ross X Ross 308 female broiler chicks (average individual weight $=43.9 \mathrm{~g}$ ), vaccinated for Marek's disease and infectious bronchitis were obtained from a commercial hatchery. Birds were randomly placed in 40 steel-cage batteries, with 10 birds per cage, in a continuous lighting program with feed and water provided ad libitum.

Corn-soybean meal all-vegetable mash diets without antibiotic growth promoters or anticoccidials were provided throughout the study. Feeding program consisted of starter feed from placement to $21 \mathrm{~d}$, and grower feed from 21 to $35 \mathrm{~d}$. Feeds had similar energy and nutrients levels after formulation according to Rostagno et al. (2005) as shown in Table 1. Treatments consisted of a Negative Control without feed additive and four graded levels of Sangrovit $(12.5,25,37.5$, and $50 \mathrm{ppm}$ ). Each treatment had 8 replications.

Birds were weekly weighed, and feed conversion ratio corrected for the weight of dead birds was calculated. Mortality was recorded daily. Data were analyzed using the Anova procedure of SAS (SAS, 2001). Tukey's test was used to assess differences between means, and values of $P \leq 0.05$ were considered statistically significant. Mortality data was analyzed after arcsin transformation.

\section{Study 2}

Four hundred one-d-old Ross X Ross 308 female

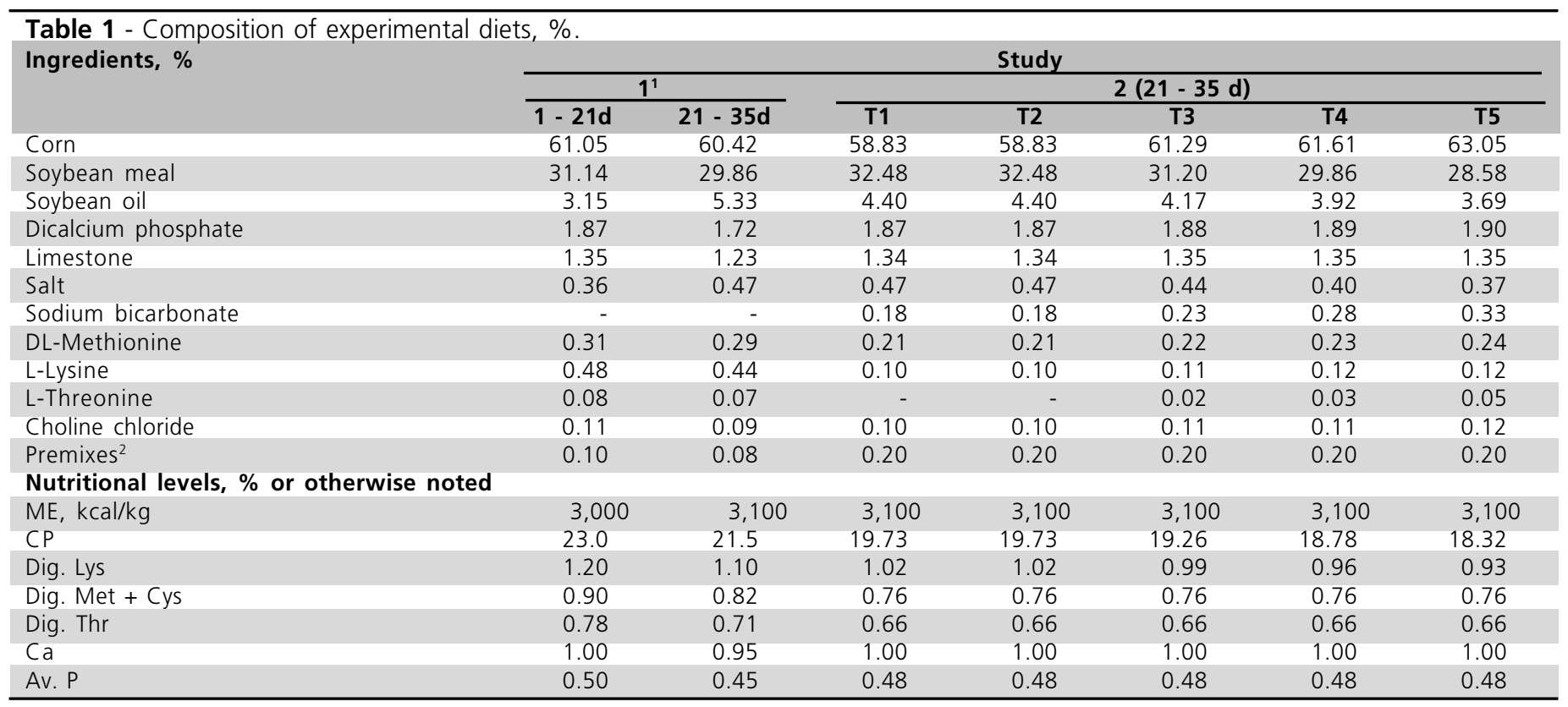

1 - Basal diets which had supplementation of Sangrovit. 2 - Vitamin and trace mineral composition per kg of feed: Vit. A: 5,000 IU; Vit. D3: 1,000 IU; Vit. E: 20 mg; Vit. K3: 0.9 mg; Vit. B1: 0.6mg; Vit. B2: 3 mg; Vit. B6: 1 mg; Pantothenic acid: 7 mg; Biotin: 0.04 mg; Folic acid: 0.5 mg; Niacin: 15 mg; Vit. B12: 6 mcg; I: 0.72 mg; Se: 0.28 mg; Cu: 8 mg; Mn: 67.5 mg; Zn: 51 mg; Fe: 64 mg. 
Vieira SL, Berres J, Reis RN, Oyarzabal OA, Coneglian JLB, Freitas DM, Peña JEM, Torres CA
Studies with Sanguinarine Like Alkaloids as Feed Additive in Broiler Diets broiler chicks vaccinated for Marek's disease and infectious bronchitis were obtained from a commercial hatchery, and randomly placed in 40 steel-cage batteries, with 10 birds per cage. Birds were submitted to a 24-h lighting program with feed and water provided ad libitum. Broilers were fed the same feed until $21 \mathrm{~d}$ of age, and then individually weighed and randomly distributed with 7 birds per cage (average individual weight $=662 \mathrm{~g}$ ).

Corn-soybean meal all-vegetable mash diets without antibiotic growth promoters or anticoccidials were provided throughout the study. Diets are shown in Table 1 and had similar energy and nutrient levels after formulation according to Rostagno et al. (2005). Treatments included a Negative Control with 19.7\% crude protein $(C P)$ without the feed additive, and diets with graded reductions of $\mathrm{CP}$ and supplemented with 20 ppm of Sangrovit as follows: 19.7, 19.2, 18.8, and $18.3 \%$. Each treatment had 8 replications. Measurements and statistical analyses were performed as in Study 1.

\section{RESULTS}

The effects of treatments on performance parameters of studies 1 and 2 are presented in Tables 2 and 3 . In both studies, mortality rate was considered normal for that time of the year and growth rate of the birds, and it was not affected by the treatments (grand means $=4.69 \%$ in Study 1 and $1.50 \%$ in Study 2).

In study 1, body weight linearly increased at $21 \mathrm{~d}$ in birds fed Sangrovit $(p \leq 0.05)$. Effects were not observed in the other periods. Feed conversion ratio corrected for the weight of dead birds improved during the total experimental period when sanguinarine were added at $37.5 \mathrm{ppm}$ to the feed in study 1 . This response was quadratically adjusted ( $\leq \leq 0.001)$ with the maximum response calculated as (-b/2a) at $32.84 \mathrm{ppm}$. Feed intake of birds fed Sangrovit improved during the first week, whereas differences were not observed ( $p \leq 0.05$ ) during the other periods.

In Study 2, body weight and feed intake were not influenced by dietary protein reductions; however, feed conversion ration was negatively affected from 21 to 28 and from 21 to $35 \mathrm{~d}$ (Table 3). Mean differences were observed only between treatments with extremes in dietary protein, but the effects of the graded reductions in protein were linear and indicate that loss in feed conversion ratio caused by these reduction were not be recovered with the addition of Sangrovit at 20 ppm.

\section{DISCUSSION}

The results from Study 1 indicate a feed conversion ratio benefit with the use of sangrovit in broilers as previously shown in swine (Tschirner et al., 2003). It has been largely accepted that sub-therapeutic doses of antimicrobials are beneficial in intensive animal production systems. However, Niewold (2007) recently suggested that expected growth promoter effects of antimicrobials on animals are in fact mediated by antiinflammatory mechanisms. Previous research studies on QBAs suggested a combination of antimicrobial and anti-inflammatory effects as an explanation for their benefits on animal performance. QBAs have antimicrobial activity (Lenfeld et al., 1981), and

\begin{tabular}{|c|c|c|c|c|c|c|c|c|c|c|c|c|c|c|c|c|c|}
\hline \multirow{3}{*}{$\begin{array}{l}\text { Sangrovit } \\
\text { mentation } \\
\text { ppm }\end{array}$} & \multicolumn{5}{|c|}{ supple- } & \multicolumn{12}{|c|}{ Days } \\
\hline & \multicolumn{5}{|c|}{ Body Weight, g } & \multicolumn{12}{|c|}{ Feed Conversion RatioFeed Intake, g } \\
\hline & 7 & 14 & $21^{2}$ & 28 & 35 & $\overline{1-7}$ & 8-14 & $15-21$ & $22-28$ & $28-35$ & $1-35^{3}$ & $1-7$ & $8-14$ & $15-21$ & $22-28$ & $28-35$ & $1-35$ \\
\hline 0 & 153 & 424 & $817 b$ & 1,340 & 1,807 & 1.29 & 1.34 & 1.51 & 1.52 & 1.79 & $1.55 b$ & $105 b$ & 364 & 589 & 798 & 838 & 2,694 \\
\hline 12.5 & 144 & 423 & $841 a b$ & 1,360 & 1,828 & 1.41 & 1.32 & 1.41 & 1.65 & 1.79 & $1.56 b$ & $140 a$ & 368 & 591 & 858 & 831 & 2,788 \\
\hline 25 & 148 & 427 & $846 a b$ & 1,362 & 1,827 & 1.34 & 1.38 & 1.42 & 1.56 & 1.80 & $1.53 \mathrm{ab}$ & $141 a$ & 371 & 599 & 819 & 828 & 2,758 \\
\hline 37.5 & 144 & 417 & $845 a b$ & 1,337 & 1,824 & 1.40 & 1.32 & 1.43 & 1.55 & 1.68 & $1.51 \mathrm{a}$ & $141 a$ & 360 & 581 & 794 & 821 & 2,697 \\
\hline 50 & 149 & 437 & $862 a$ & 1,390 & 1,863 & 1.31 & 1.29 & 1.44 & 1.57 & 1.85 & $1.55 b$ & $138 a$ & 371 & 613 & 851 & 852 & 2,825 \\
\hline Mean & 147 & 426 & 838 & 1,358 & 1,830 & 1.35 & 1.33 & 1.44 & 1.57 & 1.78 & 1.54 & 133 & 367 & 594 & 824 & 834 & 2,752 \\
\hline Probability & 0.415 & 0.140 & 0.030 & 0.258 & 0.342 & 0.324 & 0.991 & 0.404 & 0.994 & 0.090 & 0.004 & 0.001 & 0.818 & 0.138 & 0.205 & 0.806 & 0.141 \\
\hline$C V, \%$ & 6.88 & 4.08 & 3.64 & 3.61 & 3.24 & 8.58 & 4.78 & 2.71 & 4.90 & 5.04 & 1.76 & 11.29 & 5.85 & 4.13 & 8.07 & 6.01 & 4.56 \\
\hline \multicolumn{18}{|l|}{ Contrasts } \\
\hline \multicolumn{18}{|l|}{ Without } \\
\hline Sangrovit & 153 & 424 & 817 & 1,340 & 1,807 & 1.29 & 1.34 & 1.51 & 1.52 & 1.79 & 1.55 & $105 b$ & 364 & 589 & 798 & 838 & 2,694 \\
\hline \multicolumn{18}{|l|}{ With } \\
\hline Sangrovit & 146 & 426 & 843 & 1,362 & 1,836 & 1.36 & 1.33 & 1.42 & 1.58 & 1.78 & 1.54 & $140 a$ & 367 & 596 & 830 & 833 & 2.767 \\
\hline Probability & 0.521 & 0.934 & 0.074 & 0.215 & 0.245 & 0.214 & 0.874 & 0.235 & 0.294 & 0.209 & 0.895 & 0.0001 & 0.673 & 0.2339 & 0.348 & 0.516 & 0.210 \\
\hline
\end{tabular}

$a, b-$ Mean values without a common superscript are different using Tukey' test $(P \leq 0.05)$. $1-$ At least $1.5 \%$ Sanguinarine. $2-Y=0.00074 X+$ $0.81784, p=0.0213, R^{2}=0.13 .3-Y=-0.00003386 X^{2}+0.00222 X+0.10876, p=0.0010, R^{2}=0.42$. 
Vieira SL, Berres J, Reis RN, Oyarzabal OA, Coneglian JLB, Freitas DM, Peña JEM, Torres CA
Studies with Sanguinarine Like Alkaloids as Feed Additive in Broiler Diets

\begin{tabular}{|c|c|c|c|c|c|c|c|c|c|}
\hline \multirow[t]{3}{*}{ Treatments } & \multicolumn{9}{|c|}{ Days } \\
\hline & \multicolumn{3}{|c|}{ Body Weight, g } & \multicolumn{3}{|c|}{ Feed Conversion } & \multicolumn{3}{|c|}{ Feed Intake, g } \\
\hline & 21 & 28 & 35 & $21-28^{2}$ & $28-35$ & $21-35^{3}$ & $21-28$ & $28-35$ & $21-35$ \\
\hline 19.73\% CP, without Sangrovit & 664 & 1,181 & 1,687 & $1.55 a$ & 1.78 & $1.66 a$ & 804 & 901 & 1,706 \\
\hline $19.73 \% C P+20$ ppm Sangrovit & 660 & 1,172 & 1,664 & $1.52 \mathrm{a}$ & 1.84 & $1.68 a b$ & 780 & 904 & 1,685 \\
\hline $19.26 \% C P+20$ ppm Sangrovit & 660 & 1,184 & 1,683 & $1.56 a$ & 1.82 & 1.69ab & 819 & 910 & 1,730 \\
\hline $18.78 \% C P+20$ ppm Sangrovit & 664 & 1,186 & 1,688 & $1.57 \mathrm{ab}$ & 1.80 & $1.68 a b$ & 816 & 902 & 1,718 \\
\hline $18.32 \% \mathrm{CP}+20$ ppm Sangrovit & 660 & 1,164 & 1,660 & $1.63 \mathrm{~b}$ & 1.83 & $1.73 b$ & 821 & 906 & 1,726 \\
\hline Mean & 662 & 1,178 & 1,672 & 1.56 & 1.82 & 1.69 & 808 & 901 & 1,710 \\
\hline Probability & 0.731 & 0.475 & 0.518 & 0.003 & 0.478 & 0.021 & 0.155 & 0.964 & 0.538 \\
\hline$C V, \%$ & 2.21 & 1.41 & 2.37 & 2.92 & 3.60 & 1.97 & 4.10 & 2.81 & 3.17 \\
\hline \multicolumn{10}{|l|}{ Contrasts } \\
\hline Without Sangovit & 664 & 1,181 & 1,687 & 1.55 & 1.78 & 1.66 & 804 & 901 & 1,706 \\
\hline With Sangrovit & 661 & 1,177 & 1,674 & 1.57 & 1.82 & 1.70 & 809 & 905 & 1,715 \\
\hline Probability & 0.947 & 0.944 & 0.908 & 0.289 & 0.519 & 0.183 & 0.740 & 0.764 & 0.745 \\
\hline
\end{tabular}

a,b - Mean values without a common superscript are different using Tukey's test $(P \leq 0.05)$. 1 - At least $1.5 \%$ Sanguinarine. $2-Y=-0.06339 X$ $+2.77502, p=0.0002, R^{2}=0.37 .3-Y=-0.03164 X+2.29767, p=0.0099, R^{2}=0.20$.

minimum inhibitory concentrations of sanguinarine against several bacteria were found in the oral cavity of humans (Dzink \& Socransky, 1985). Many of these bacteria belong to species commonly found in the gastrointestinal tract of chickens. Therefore, sanguinarine effects against them are expected by analogy. In parallel, it is possible to speculate that sanguinarine activity as an anti-inflammatory substance may play a role in the partial improvements obtained in the broilers of Study 1. For instance, antiinflammatory activity has been largely demonstrated with various QBA's, including sanguinarine (Lenfeld et al., 1981; Agarwal et al., 1991). In pig intestines, this activity is expected to be caused mostly by contact, since the bulk of these alkaloids are excreted in the feces, and only a very small proportion is absorbed (Kosina et al., 2004).

Sanguinarine has been shown to reduce intestinal decarboxylation of aromatic amino acids through the inhibition of L-amino acid decarboxylase in swine (Drsata et al., 1996). The rationale for reducing dietary protein in Study 2 was to investigate a possible similar effect in broilers. The performance obtained with the graded $C P$ reductions appeared to be sustained to the level of $18.78 \%$ CP for feed conversion rate and of $18.32 \%$ for body weight and feed intake. However, protein retention measurements should be conducted to conclude that the impact of the reduction in protein was counteracted by the supplementation of the additive.

If Niewold's (2007) theory is correct, the search for alternatives to traditional antibiotic growth promoters does not necessarily mean a search for alternative antimicrobials. Sanguinarine, as some of other QBAs, has several interesting characteristics as a feed additive for broilers. Most of these characteristics support the benefits in body weight and feed conversion ratio observed in this study.

\section{CONCLUSIONS}

1. Dietary supplementation with sangrovit significantly improved body weight at 21 days, feed conversion ratio at 35 days, and feed intake at 7 days of age. While body weight was linearly affected by 50 ppm of Sangrovit at 21 days, feed conversion ratio at 35 days was maximized at the supplementation level of $32.8 \mathrm{ppm}$ of Sangrovit.

2. Body weight and feed intake were not affected when broilers were fed diets with graded reductions of crude protein; however, feed conversion ratio was negatively affected when with protein levels of $18.78 \%$ and lower.

\section{REFERENCES}

Agarwal S, Reynolds MA, Pou S, Peterson DE, Charon JA, Suzuki JB. The effect of sanguinarine on human peripheral blood neutrophil viability and functions. Oral Microbiology and Immunology 1991; 6:51-61.

Chaturverdi MM, Kumar A, Darnay BG, Chainy GBN, Agarwal S, Aggarwal BB. Sanguinarine (pseudochelerythrine) is a potent inhibitor of NP-kappa B activation, I kappa B alpha phosphorylation, and degradation. Journal of Biological Chemistry 1997; 272(48): 30129-30134

Colombo ML, Bosisio E. Pharmacological activities of Chelidonium majus L. (Papaveraceae). Pharmacological Research 1996; 33:127134 


\section{Vieira SL, Berres J, Reis RN, Oyarzabal OA, Coneglian JLB, Freitas DM, Peña JEM, Torres CA}

Studies with Sanguinarine Like Alkaloids as Feed Additive in Broiler Diets
Dickens JA, Ingram KD. Efficacy of an Herbal Extract, at Various Concentrations, on the Microbiological Quality of Broiler Carcasses After Simulated Chilling. Journal Applied Poultry Research 2001; 10:194-198.

Drsata J, Ulrichova J, Walterova D. Sanguinarine and chelerythrine as inhibitor of aromatic amino acid descarboxylase. Journal of Enzime Inhibition 1996; 10:231-237.

Dzink JL, Socransky SS. Comparative in vitro activity of sanguinarine against oral microbial isolates. Antimicrobial Agents and Chemotherapy 1985; 27:663-665.

Eisenberg AD, Young DA, Fan-Hsu J, Spitz LM. Interaction of sanguinarine and zinc on oral streptococci and Actinomyces species. Caries Research 1991; 25:185-190.

Kosina P, Walterová D, Ulrichová J, Lichnovský V, Stiborová M, Rýdlová H, Vicar J, Krecman V, Brabec MJ, Simánek V. Sanguinarine and chelerythrine: assessment of safety on pigs in ninety days feeding experiment. Food and Chemical Toxicology 2004; 42:8591.

Lenfeld J, Kroutil M, Marsálek E, Slavík J, Preininger V, Simánek V. Antiinflammatory activity of quaternary benzophenanthridine alkaloids from Chelidonium majus. Planta Medica 1981; 43:161165.

Mellor S. Natural appetisers from plants. Feed Mix 2001; 9:29-31.

Newton SM, Lau C, Gurcha SS, Besra GS, Wright CW. The evaluation of forty-three plant species for in vitro antimycobacterial activities; isolation of active constituents from Psoralea corylifolia and Sanguinaria canadensis. Journal Ethnopharmacology 2002; 79:5767.

Niewold TA. The non antibiotic anti-inflammatory effect of antimicrobial growth promoters, the real mode of action? A hypothesis. Poultry Science 2007; 86:605-609.

Rostagno HS, Albino LFT, Donzele JL, Gomes PC, Oliveira RF de, Lopes DC, Ferreira AS, Barreto SLT. Tabelas brasileiras para aves e suínos. composição de alimentos e exigências nutricionais. 2nd ed. Viçosa: UFV; 2005.

SAS Institute. SAS/STAT User's guide: release 8.0. Cary; 2001.

Shea KM. Nontherapeutic use of antimicrobial agents in animal agriculture: implications for pediatrics. Pediatrics 2004; 114:862868.

Tschirner K, Susenbeth A, Wolffram S. Influence of Sangrovit ${ }^{\circledR}$ supplementation on nitrogen balance and feed intake in growing pigs. 9th Symposium Vitamins and Additives in the Nutrition of Man and Animal; 2003 sep. 24-25; Jena: Friedrich Schiller University; 2003. p.45

Tanaka T, Metori K, Mineo S, Hirotani M, Furuya T, Kobayashi S. Inhibitory effects of berberine-type alkaloids on elastase. Planta Medica 1993; 59:200-202.
Tschirner K. Untersuchungen zur wirksamkeit und zum nachweis des pflanzlichen alkaloids sanguinarin beim schwein [dissertation]. Kiel: Christian Albrechts Universität Kiel; 2004. 